\title{
PARAMETRI ANTROPOGENOG ZBIJANJA, KVARENJA STRUKTURE I STVARANJA POKORICE KOD RAZLIČITIH NAČINA OBRADE TLA
}

\author{
PARAMETERS OF ANTHROPOGENIC COMPACTION, \\ SOIL STRUCTURE DEGRADATION AND CRUST FORMATION \\ IN DIFFERENT TILLAGE METHODS
}

\author{
A. Špoljar, Ivka Kvaternjak, I. Kisić
}

\section{SAŽETAK}

Istraživanja su provedena na pokušalištu Visokog gospodarskog učilišta u Križevcima (N: $\left.46^{\circ} 01^{1} 12^{11} \mathrm{E}: 16^{\circ} 34^{\mathrm{l}} 28^{11}\right)$. Istraživani su načini (varijante) obrade tla s manjim i većim brojem zahvata dopunske obrade uz korištenje različitih ratila s jesenskim i proljetnim rokom osnovne obrade. Na pet varijanata obrade tla uzgajani su jari usjevi u plodosmjeni: kukuruz (Zea mays L.) u 2008. godini i soja (Glycine max L.) u 2009. Cilj istraživanja bio je utvrditi utjecaj različitih načina i rokova obrade na antropogeno zbijanje, kvarenje strukture i opasnost od stvaranja pokorice, kako bi se mogao preporučiti najpovoljniji način i rok obrade tla. Izračunati su sljedeći fizikalni parametri: omjer disperzije (DR), omjer disperzije gline (CDR), indeks flokulacije (CFI), koeficijent pora (e), gustoća pakiranja čestica $(\mathrm{Gp})$, rizik od stvaranja pokorice $(\mathrm{R})$ i parametar stabilnosti strukturnih agregata (St). Najpovoljnije stanje stabilnosti strukture (St), utvrđeno je kod varijante gdje je osnovna obrada i priprema tla sjetvospremačem provedena u proljeće, dok je najnepovoljnije stanje utvrđeno kod varijante s najvećim brojem zahvata obrade (varijanta E). Najveća vrijednost ovog parametra i najmanja opasnost od zbijanja tla i erozije zabilježena je nakon uzgoja soje. Najveće vrijednosti gustoće pakiranja čestica tla (Gp) nakon berbe kukuruza bile su kod varijanata kod kojih je osnovna obrada tla provedena u jesen, a predsjetvena priprema tanjuračom i sjetvo-spremačem (varijante D i E). U obje godine istraživanja utvrđen je najmanji rizik od stvaranja pokorice (R) kod varijante s proljetnim oranjem i pripreme tla sjetvospremačem, a najveća vrijednost ovog parametra i ujedno najpovoljnije stanje bilo je nakon uzgoja soje. Temeljem navedenoga, sa stanovišta održivog gospodarenja tlom, na pseudogleju pjeskovito ilovaste teksture može se preporučiti osnovna obrada tla u proljeće i njegova priprema sjetvo-spremačem.

Ključne riječi: obrada tla, parametri antropogenog zbijanja 
A. Špoljar i sur.: Parametri antropogenog zbijanja, kvarenja strukture i stvaranja pokorice kod različitih načina obrade tla

\begin{abstract}
Research was conducted at Križevci College of Agriculture (N: $46^{\circ} 01^{1} 12^{11}$ E: $16^{0} 34^{1} 28^{11}$ ). Different tillage methods (variants) were studied with a smaller and larger number of secondary tillage treatments using different tools for tilling during the autumn and spring period of primary tillage. The following crops were cultivated on five different variants of soil cultivation in crops rotation: corn (Zea mays L.) in 2008 and soybean (Glycine max L.) in 2009. The aim of the research was to determine the influence of different methods and treatment times on anthropogenic compaction, structure deformation and the risk of crust formation, in order to recommend the optimal method and time of soil tillage. The following physical parameters were calculated: dispersion ratio (DR), clay dispersion ratio (CDR), flocculant index (CFI), pore coefficient (e), particle density (Gp), risk of crust formation (R) and stability parameter of structural aggregates (St). The most favourable condition of structure stability (St) was found in the variant in which primary tillage and soil preparation with seedbed cultivator was carried out in the spring, while the most unfavourable condition was found in the variant with the largest number of treatments. The highest value of this parameter and the lowest risk of soil compaction and erosion was observed after soybean growing. The highest density values of the soil particle size (PD) after corn harvesting were in the variants where the primary tillage was carried out in autumn and preparation of the soil before sowing with discs and seedbed cultivator. In both research years, the lowest risk of crust formation $(\mathrm{R})$ was determined in the variant with spring primary tillage and preparation of the soil before sowing with seedbed cultivator, and the highest value of this parameter and the most favourable condition were after soybean cultivation. From the point of sustainable soil management and based on the facts mentioned above, primary tillage, as well as its preparation with a seedbed cultivator, is recommended in the spring.
\end{abstract}

Keywords: soil tillage, anthropogenic compaction parameters

\title{
UVOD
}

Obrada tla temeljni je zahvat o kojem ovisi uspjeh biljne proizvodnje. Njezin je zadatak poboljšati strukturu tla i povećati sadržaj pora, stvoriti povoljnije uvjete za klijanje i nicanje te rast i razvoj uzgajanih usjeva. Međutim, konvencionalni uzgoj koji obuhvaća veliki broj zahvata u pripremi tla za sjetvu može dovesti do zbijanja, kvarenja strukture i stvaranja pokorice te smanjenja 
A. Špoljar i sur.: Parametri antropogenog zbijanja, kvarenja strukture i stvaranja pokorice kod različitih načina obrade tla

sadržaja organske tvari. Zbog toga je ograničen razvoj korijenovog sustava, slabije je nicanje i smanjuje se infiltracijska sposobnost tla.

Dorner i sur. (2011.) utvrđuju, kako intenziviranje korištenja zemljišta dovodi do većih mehaničkih $i$ hidrauličkih naprezanja $u$ tlu, što rezultira smanjenjem poroznosti tla te povećanjem volumne gustoće. Autori ističu da se kao posljedica smanjenja sadržaja makro pora u tlu smanjuje propusnost tla za zrak. Bogunović i sur. (2014.) navode, kako je zbijenost tla značajan ograničavajući čimbenik u biljnoj proizvodnji, a glavni uzrok degradacije tla su suvremene tehnologije koje se koriste u poljoprivredi. Shah i sur. (2017.) ističu, kako je nepovoljni sadržaj vlage u tlu jedan od bitnih čimbenika povećanja mehaničkog otpora tla.

Guan i sur. (2015.) utvrđuju manje vrijednosti mehaničkog otpora tla i manju volumnu gustoću na obrađenom tlu u usporedbi $\mathrm{s}$ izostavljenom obradom. Pagliai i sur. (2004.) dobivaju manju stabilnost strukturnih agregata pri obradi tla lemešnim plugom $\mathrm{s}$ većom opasnošću od stvaranja pokorice $u$ odnosu na provedenu reduciranu obradu i podrivanje. Autori također preporučaju glede povećanja stabilnosti strukture tla i ukupnog poroziteta primjenu komposta i drugih organskih gnojiva. Kod stabilne strukture tla, kako navode, smanjuje se opasnost od stvaranja pokorice. Oduma i sur. (2017.) ističu da se pravovremenom i prilagođenom osnovnom obradom i predsjetvenom pripremom može poboljšati struktura tla, smanjiti mehanički otpor te stvoriti povoljniji uvjeti za razvoj korijenovog sustava.

Glede toga, cilj istraživanja bio je utvrditi utjecaj različitih načina obrade na antropogeno zbijanje, kvarenje strukture i opasnost od stvaranja pokorice, kako bi se mogao preporučiti najpovoljniji način i rok obrade tla.

\section{MATERIJAL I METODE}

Istraživanja su provedena na pseudogleju obronačnom, eutričnom na pokušalištu Visokog gospodarskog učilišta u Križevcima (N: $46^{\circ} 01^{1} 12^{11}$ E: $\left.16^{\circ} 34^{\mathrm{l}} 28^{\mathrm{ll}}\right)$. Na pet različitih varijanata obrade tla uzgajani su jari usjevi u plodosmjeni: kukuruz (Zea mays L.) u 2008. godini i soja (Glycine max L.) u 2009. Istraživane varijante obrade tla bile su: osnovna obrada u proljeće i dopunska neposredno prije sjetve sjetvo-spremačem - varijanta A, osnovna obrada u proljeće i dopunska rotirajućom drljačom - varijanta $\mathrm{B}$, osnovna obrada u jesen i dopunska klinastom i rotirajućom drljačom - varijanta $\mathrm{C}$, 
A. Špoljar i sur.: Parametri antropogenog zbijanja, kvarenja strukture i stvaranja pokorice kod različitih načina obrade tla

osnovna obrada u jesen i dopunska klinastom drljačom i sjetvo-spremačem varijanta $D$ te varijanta $E$ gdje je osnovna obrada obavljena u jesen i dopunska klinastom drljačom, tanjuračom i sjetvo-spremačem.

Izračunat je omjer disperzije (DR), omjer disperzije gline (CDR), indeks flokulacije (CFI) i stabilnost strukturnih agregata (St), (Gabriels i Verdoodt, 2012.).

Za izračun navedenih parametara korištene su sljedeće jednadžbe:

$$
\mathrm{DR}=\frac{\mathrm{WDprah}+\mathrm{WDglina}}{\text { prah }+ \text { glina }}
$$

gdje je WDprah frakcija disperziranog praha u vodi (\%), a Wdglina je frakcija disperzirane gline u vodi (\%).

$$
\begin{aligned}
& \mathrm{CDR}=\frac{\text { WDglina }}{\text { glina }} \\
& \mathrm{CFI}=\frac{\text { glina }- \text { WDglina }}{\text { glina }} \\
& \mathrm{St}=\frac{\text { SOM }}{\text { sadržaj gline i praha }},
\end{aligned}
$$

gdje je SOM sadržaj organske tvari u tlu (\%).

Vrijednosti parametara DR, CDR i CFI kreću se od 0 do 1 . Veće vrijednosti CDR-a i DR-a ukazuju na povećanu sklonost tla disperziji, dok veće vrijednosti CFI-ja označavaju bolju stabilnost strukturnih agregata. Vrijednosti stabilnosti strukturnih agregata $(\mathrm{St})$ manje od $5 \%$ predstavljaju gubitak strukture tla $\mathrm{s}$ visokom osjetljivošću na eroziju, vrijednosti od 5\% do $9 \%$ označavaju nestabilnu strukturu i rizik od degradacije tla, a struktura tla je stabilna, ako su one veće od $9 \%$.

Za karakterizaciju stanja zbijenosti tla izračunat je koeficijent pora (e) i gustoća pakiranja čestica $(\mathrm{Gp})$. Jednadžbu za izračun gustoće pakiranja čestica (Gp) daju Beneck i Renger (cit. prema SSEW, 1976.):

$$
\mathrm{Gp}=\rho_{\mathrm{v}}+0,009 \cdot \% \text { gline, } \mathrm{g} / \mathrm{cm}^{3}
$$

gdje je $\rho_{\mathrm{v}}$ volumna gustoća tla. 
A. Špoljar i sur.: Parametri antropogenog zbijanja, kvarenja strukture i stvaranja pokorice kod različitih načina obrade tla

Vrijednosti manje od $1,40 \mathrm{gcm}^{-3}$ predstavljaju slabo zbijeno tlo, od $1,40 \mathrm{~g} \mathrm{~cm}^{-3}$ do $1,75 \mathrm{~g} \mathrm{~cm}^{-3}$ srednje zbijeno, a jako zbijeno tlo je ako su ove vrijednosti veće od $1,75 \mathrm{~g} \mathrm{~cm}^{-3}$.

Koeficijent pora (e) izračunat je prema jednadžbama Hillela (cit. Racz, 1981.):

$$
\mathrm{n}=\frac{\mathrm{P}}{100}, \mathrm{n}=\frac{e}{1+e}, \text { ili } \mathrm{e}=\frac{n}{1-n}
$$

gdje je $\mathrm{n}$ relativna poroznost, a $\mathrm{P}$ je ukupni porozitet.

Iz podataka o sadržaju humusa $i$ na temelju postotnog udjela praha $\mathrm{i}$ gline $\mathrm{u}$ tlu izračunat je rizik od stvaranja pokorice (R), (https://www.polj.savetodavstvo.gov.vojvodina.rs). Za izračun rizika od stvaranja pokorice $(\mathrm{R})$ korištena je sljedeća jednadžba:

$$
\mathrm{R}=\frac{\mathrm{H} \cdot 100}{(\mathrm{Pr}+\mathrm{G})}, \text { gdje je }
$$

$\mathrm{H}=$ sadržaj humusa u tlu, (\%)

$(\operatorname{Pr}+\mathrm{G})=$ sadržaj praha i gline u tlu, $(\%)$.

Vrijednosti R veće od 5 predstavljaju velik rizik od pokorice, oko 7 osrednji i veće od 9 označavaju malen rizik od stvaranja pokorice.

Za potrebe izračuna parametara zbijenosti tla, kvarenja strukture i opasnosti od stvaranja pokorice određen je mehanički sastav tla u vodi i u natrijevom pirofosfatu (HRN ISO 11277:2004), gustoće tla (HRN ISO 11272:2004) i sadržaj humusa prema metodi Tjurina. Gustoće tla su određene u šesnaest, a sadržaj humusa prema metodi Tjurina u četiri ponavljanja. Parametar stabilnosti strukturnih agregata $(\mathrm{St})$ i rizika od stvaranja pokorice (R) prikazuje stanje strukture tla, osjetljivosti od erozije i opasnosti od stvaranja pokorice nakon berbe kukuruza te nakon žetve soje. Gustoća pakiranja čestica (Gp) i koeficijent pora (e) ukazuju na stanje zbijenosti tla nakon nicanja i berbe kukuruza te nakon nicanja i žetve soje. Svi navedeni parametri izračunati su za dubinu do $30 \mathrm{~cm}$. Podaci su statistički obrađeni analizom varijance (ANOVA), statističkim programom Statistica 12.1. (StafSoft, Inc. 2012.). Srednje vrijednosti uspoređene su HSD Tukey testom. 
A. Špoljar i sur.: Parametri antropogenog zbijanja, kvarenja strukture i stvaranja pokorice kod različitih načina obrade tla

\section{REZULTATI I RASPRAVA}

Iz podataka o mehaničkom sastavu tla, koji je određen 2007. godine izračunat je omjer disperzije (DR), omjer disperzije gline (CDR) i indeks flokulacije (CFI), a podaci su prikazani u tablici 1.

Tablica 1. Rezultati mehaničkog sastava tla u vodi i u natrijevom pirofosfatu i parametri disperzije strukturnih agregata

Table 1 Results of mechanical analysis of soil in water and sodium pyrophosphate and aggregate structural dispersion parameters

\begin{tabular}{|c|c|c|c|c|c|c|c|c|}
\hline \multirow[b]{2}{*}{$\begin{array}{c}\text { Dubina, } \\
\text { Depth, } \\
\text { cm }\end{array}$} & \multicolumn{4}{|c|}{$\begin{array}{l}\text { Teksturne klase, } \\
\text { Texture classes }\end{array}$} & \multirow{2}{*}{$\begin{array}{l}\text { Teksturna } \\
\text { oznaka, } \\
\text { Textural } \\
\text { designation, } \\
\text { (SSEW, } \\
\text { 1976.) }\end{array}$} & \multirow{2}{*}{$\begin{array}{c}\text { Omjer } \\
\text { disperzije, } \\
\text { Dispersion } \\
\text { ratio, } \\
\text { (DR) }\end{array}$} & \multirow{2}{*}{$\begin{array}{c}\text { Omjer } \\
\text { disperzije } \\
\text { gline, } \\
\text { Clay } \\
\text { dispersion } \\
\text { ratio, } \\
\text { (CDR) }\end{array}$} & \multirow{2}{*}{$\begin{array}{l}\text { Indeks } \\
\text { flokulacije, } \\
\text { Flocculation } \\
\text { index, } \\
\text { (CFI) }\end{array}$} \\
\hline & $\begin{array}{c}2- \\
0,2 \\
\mathrm{~mm}\end{array}$ & $\begin{array}{l}0,2- \\
0,02 \\
\mathrm{~mm}\end{array}$ & $\begin{array}{c}0,02- \\
0,002 \\
\mathrm{~mm}\end{array}$ & $\begin{array}{c}<0,002 \\
\mathrm{~mm}\end{array}$ & & & & \\
\hline \multicolumn{6}{|c|}{$\begin{array}{l}\text { Analiza mehaničkog sastava tla u vodi, } \\
\text { Mechanical analysis of soil in water, \% }\end{array}$} & \multirow{4}{*}{0,96} & \multirow{4}{*}{0,63} & \multirow{4}{*}{0,37} \\
\hline $0-30$ & 2,08 & 56,77 & 35,90 & 5,25 & PI & & & \\
\hline \multicolumn{6}{|c|}{$\begin{array}{l}\text { Analiza mehaničkog sastava tla u Na-pirofosfatu, } \\
\text { Mechanical analysis of soil in Na-pyrophosphate, } \%\end{array}$} & & & \\
\hline $0-30$ & 1,43 & 55,92 & 34,35 & 8,30 & PI & & & \\
\hline
\end{tabular}

Omjer disperzije (DR) iznosio je 0,96, omjer disperzije gline (CDR) 0,63 i indeks flokulacije (CFI) 0,37. Izračunate vrijednosti parametara DR i CDR ukazuju na povećanu sklonost tla disperziji, a vrijednost CFI ukazuje na manju stabilnost strukturnih agregata. Tablica 2. prikazuje rezultate stabilnosti strukturnih agregata $(\mathrm{St})$ i gustoće pakiranja čestica $(\mathrm{Gp})$ po varijantama obrade. Vrijednosti stabilnosti strukturnih agregata (St) manje od 5 ukazuju na kvarenje strukture i visoku osjetljivost tla na erozijske procese. Statistički opravdano veće vrijednosti parametra $(\mathrm{St})$ nakon berbe kukuruza utvrđene su kod varijanata $\mathrm{A}, \mathrm{C}$ i D u odnosu na varijante $\mathrm{B}$ i E. Slični rezultati dobiveni su i kod uzgoja soje sa značajno većim vrijednostima ovog parametra kod varijanata A, B, C i D u odnosu na varijantu E. Ipak je najpovoljnije stanje ovog parametra, kako je razvidno iz podataka, utvrđeno kod varijante A, kod koje je osnovna obrada i priprema tla za sjetvu obavljena sjetvo-spremačem u proljeće, dok je najnepovoljnije stanje utvrđeno kod varijante $\mathrm{E} s$ najvećim brojem zahvata obrade. Najveća vrijednost ovog parametra i najmanja opasnost od zbijanja tla i erozije zabilježena je nakon uzgoja soje. 
A. Špoljar i sur.: Parametri antropogenog zbijanja, kvarenja strukture i stvaranja pokorice kod različitih načina obrade tla

Glede gustoće pakiranja čestica (Gp) pri uzgoju kukuruza nakon berbe nisu utvrđene statistički opravdane razlike između varijanata obrade. Značajno manje vrijednosti ovog parametra kod uzgoja kukuruza utvrđene su u stadiju nicanja kod varijante $\mathrm{B}$ u odnosu na ostale istraživane načine obrade. Međutim, ipak su najveće vrijednosti gustoće pakiranja čestica zabilježene nakon nicanja kod varijante $\mathrm{E}$ i nakon berbe kukuruza kod varijanata D i E. Između istraživanih varijanata obrade tla pri uzgoju soje također nisu utvrđene statistički opravdane razlike vrijednosti gustoće pakiranja čestica (Gp).

Tablica 2. Stabilnost strukturnih agregata (St) i gustoća pakiranja čestica (Gp) pri različitim varijantama obrade tla

Table 2 Soil structure stability (St) and packing density (PD) in different soil tillage methods

\begin{tabular}{|c|c|c|c|c|c|}
\hline \multirow{2}{*}{ Parametar, Parameter } & \multicolumn{5}{|c|}{$\begin{array}{l}\text { Varijante obrade, } \\
\text { Variants of tillage }\end{array}$} \\
\hline & A & B & $\mathrm{C}$ & $\mathrm{D}$ & $\mathrm{E}$ \\
\hline $\begin{array}{l}\text { Stabilnost strukturnih agregata }(\mathrm{St}), \% \\
\text { - nakon berbe kukuruza } \\
\text { Soil structure stability }(\mathrm{St}) \text { - after the harvest of corn }\end{array}$ & $5,09^{b}$ & $4,26^{\mathrm{a}}$ & $5,00^{\mathrm{b}}$ & $4,99^{\mathrm{b}}$ & $4,14^{\mathrm{a}}$ \\
\hline $\begin{array}{l}\text { Stabilnost strukturnih agregata, }(\mathrm{St}), \% \text { - nakon žetve soje } \\
\text { Soil structure stability }(\mathrm{St}) \text { - after the harvest of soybean }\end{array}$ & $5,28^{b}$ & $4,79^{\mathrm{b}}$ & $4,78^{\mathrm{b}}$ & $4,95^{\mathrm{b}}$ & $4,27^{\mathrm{a}}$ \\
\hline $\begin{array}{l}\text { Gustoća pakiranja čestica }(\mathrm{Gp}), \mathrm{g} \mathrm{cm}^{-3} \\
\text { - nakon nicanja kukuruza } \\
\text { Packing density }(\mathrm{PD}), \mathrm{g} \mathrm{cm}^{-3}-\text { after the germination of corn }\end{array}$ & $1,50^{\mathrm{a}}$ & $1,49^{b}$ & $1,54^{\mathrm{a}}$ & $1,51^{\mathrm{a}}$ & $1,57^{\mathrm{a}}$ \\
\hline $\begin{array}{l}\text { Gustoća pakiranja čestica }(\mathrm{Gp}), \mathrm{g} \mathrm{cm}^{-3} \\
\text { - nakon berbe kukuruza } \\
\text { Packing density }(\mathrm{PD}), \mathrm{gcm}^{-3}-\text { after the harvest of corn }\end{array}$ & $1,53^{\mathrm{a}}$ & $1,55^{\mathrm{a}}$ & $1,54^{\mathrm{a}}$ & $1,58^{a}$ & $1,57^{\mathrm{a}}$ \\
\hline $\begin{array}{l}\text { Gustoća pakiranja čestica }(\mathrm{Gp}), \mathrm{g} \mathrm{cm}^{-3}-\text { nakon nicanja soje } \\
\text { Packing density }(\mathrm{PD}), \mathrm{g} \mathrm{cm}^{-3} \\
\text { - after the germination of soybean }\end{array}$ & $1,56^{\mathrm{a}}$ & $1,53^{\mathrm{a}}$ & $1,54^{\mathrm{a}}$ & $1,54^{\mathrm{a}}$ & $1,59^{\mathrm{a}}$ \\
\hline $\begin{array}{l}\text { Gustoća pakiranja čestica }(\mathrm{Gp}), \mathrm{g} \mathrm{cm}^{-3}-\text { nakon žetve soje } \\
\text { Packing density (PD), } \mathrm{g} \mathrm{cm}^{-3}-\text { after the harvest of soybean }\end{array}$ & $1,61^{\mathrm{a}}$ & $1,60^{\mathrm{a}}$ & $1,55^{\mathrm{a}}$ & $1,56^{\mathrm{a}}$ & $1,56^{\mathrm{a}}$ \\
\hline
\end{tabular}

*vrijednosti u redovima označene različitim slovima značajno se razlikuju

* the values in rows marked with different letters differ significantly

Nakon nicanja soje najveća vrijednost gustoće pakiranja čestica (Gp) utvrđena je kod varijante E, a nakon žetve kod varijante A. Također su pri uzgoju soje na varijanti $\mathrm{E}$ utvrđene manje vrijednosti gustoće pakiranja čestica (Gp) u žetvi u odnosu na stadij nicanja, što može biti rezultat utjecaja uzgajane kulture. Kod ostalih istraživanih varijanata pri uzgoju soje tijekom vegetacije došlo je do povećanja vrijednosti gustoće pakiranja čestica (Gp). Kako je iz 
podataka vidljivo, uglavnom je, temeljem gustoće pakiranja čestica (Gp) utvrđeno najnepovoljnije stanje zbijenosti tla kod varijante $\mathrm{E}$ s najvećim brojem zahvata proljetne obrade. Bez obzira na činjenicu da su najpovoljniji rezultati istraživanih značajki tla postignuti uglavnom na varijanti A kod koje je osnovna obrada provedena $\mathrm{u}$ proljeće i dopunska neposredno prije sjetve sjetvospremačem Kvaternjak i sur. (2015.) u agroekološkim uvjetima sjeverozapadne Hrvatske postižu najveće prinose kukuruza na varijanti $\mathrm{B}$, a soje na varijanti $\mathrm{E}$. Međutim, sa stanovišta održivog gospodarenja tlom s ciljem njegovog očuvanja može se preporučiti osnovna obrada tla u proljeće i priprema sjetvo-spremačem.

Kozlowski (2008.) navodi kako se prekomjerna zbijenost tla može nepovoljno odraziti na rast i razvoj usjeva te na njihove prinose. Autor ističe da izrazito zbijena tla imaju nepovoljnu strukturu, povećanu volumnu gustoću, manju propusnost za vodu, slabu aeraciju, povećano površinsko otjecanje vode i izražene erozijske procese. Povećana zbijenost tla može dovesti do fizioloških poremećaja u biljci, kao što su poremećaj hormona rasta i smanjena fotosintetska aktivnost. Pri istraživanju mehaničkog otpora tla u vinogradima različite starosti Špoljar i sur. (2014.) utvrđuju nepovoljnije uvjete zbijenosti tla kod starih vinograda u odnosu na novopodignute. Autori također utvrđuju veće vrijednosti mehaničkog otpora tla $\mathrm{u}$ tragu kotača $\mathrm{u}$ odnosu na vrijednosti izmjerene u sredini između kotača. To je, kako navode, rezultat intenzivnog uzgoja vinove loze, pri čemu se između redova ,prometuje“ petnaest do dvadeset puta godišnje. Utvrđene vrijednosti mehaničkog otpora tla u tragu i izvan traga kotača, uglavnom su veće od $2 \mathrm{MPa}$, koje prema Bahamu 1999. (cit. Špoljar i sur., 2014.) nepovoljno utječu na razvoj korijenovog sustava. Sa stanovišta održivog gospodarenja tlom autori preporučaju upotrebu lakše mehanizacije i smanjivanje broja prohoda.

Krebstein i sur. (2013) ističu, kako je zbijanje tla na obradivim površinama nepovoljno utjecalo na distribuciju pora, kapacitet tla za zrak i njegovu provodljivost, kao i hidrauličku provodljivost saturiranog tla. Batey (2009.) također navodi, kako su nepoželjni učinci zbijanja tla povezani sa smanjenom propusnosti tla za vodu i zrak te je ograničen rast korijenovog sustava. Zbijanje tla, kako navodi autor, nije isključivo vezano za poljoprivredno i šumsko tlo te za rekreacijska područja, već se problem zbijenosti pojavljuje i u prirodnim tlima te je $\mathrm{u}$ vezi $\mathrm{s}$ klimatskim prilikama. Izraziti nedostaci vode mogu nepovoljno utjecati na razvoj korijenovog sustava, dok ista razina zbijenosti može imati zanemariv utjecaj kod manjih nedostataka vode. Da zbijane tla ima nepovoljan utjecaj na razvoj korijenovog sustava upozoravaju Tracy i sur. (2011). Autori navode, kako zbijanje tla utječe na povećanje čvrstoće tla, a 
A. Špoljar i sur.: Parametri antropogenog zbijanja, kvarenja strukture i stvaranja pokorice kod različitih načina obrade tla

istovremeno se smanjuje prozračnost i hidraulička provodljivost tla. Na štetne posljedice prekomjerne zbijenosti tla upozoravaju i drugi autori (Frey i sur., 2009; Martinez i Zinck 2004; Soane i Van Ouwerkerk1995.).

Tablica 3. prikazuje srednje vrijednosti parametra zbijanja tla i rizika od stvaranja pokorice (R). Vrijednosti parametra (R) manje od 5 predstavljaju velik rizik od stvaranja pokorice, a one veće od 9 ukazuju na malen rizik od pokorice. Statistički opravdano veće vrijednosti parametra $R$, koji ukazuje na manju opasnost od stvaranja pokorice utvrđene su pri uzgoju kukuruza kod varijanata A, C i D u odnosu na druge istraživane načine obrade tla. Pri uzgoju soje opravdano veće vrijednosti parametra $R$ bile su kod varijanata $A, B, C$ i D u odnosu na varijantu E. Najveće vrijednosti rizika od stvaranja pokorice $(\mathrm{R}) \mathrm{u}$ obje istraživane godine utvrđene su nakon berbe kukuruza i žetve soje kod varijante A s osnovnom i dopunskom obradom provedenom $\mathrm{u}$ proljeće. Najpovoljnije stanje ovog parametra utvrđeno je nakon uzgoja soje. Slične rezultate pri uzgoju usjeva u plodoredu dobivaju Špoljar i sur. (2011.). Nakon četverogodišnjeg pokusa autori utvrđuju najpovoljnije stanje zbijenosti tla i najmanju opasnost od stvaranja pokorice nakon uzgoja lupine.

Tablica 3. Srednje vrijednosti parametara zbijanja tla i rizika od stvaranja pokorice pri različitim načinima obrade tla

Table 3 Mean values of soil compaction parameters and risk of crust formation in different soil tillage methods

\begin{tabular}{|l|c|c|c|c|c|}
\hline \multirow{2}{*}{ Parametar, Parameter } & \multicolumn{4}{|c|}{ Varijante obrade, Variants of tillage } \\
\cline { 2 - 6 } & A & B & C & D & E \\
\hline $\begin{array}{l}\text { Rizik od stvaranja pokorice, R - nakon berbe } \\
\text { kukuruza } \\
\text { Risk of crust formation, R - after the harvest of corn }\end{array}$ & $\mathbf{1 1 , 9 4 ^ { \mathrm { a } }}$ & $9,98^{\mathrm{b}}$ & $11,74^{\mathrm{a}}$ & $11,71^{\mathrm{a}}$ & $9,72^{\mathrm{b}}$ \\
\hline $\begin{array}{l}\text { Rizik od stvaranja pokorice R - nakon žetve soje } \\
\text { Risk of crust formation, R - after the harvest of } \\
\text { soybean }\end{array}$ & $\mathbf{1 2 , 3 8 ^ { \mathrm { a } }}$ & $11,23^{\mathrm{a}}$ & $11,22^{\mathrm{a}}$ & $11,61^{\mathrm{a}}$ & $10,02^{\mathrm{b}}$ \\
\hline $\begin{array}{l}\text { Koeficijent pora, e - nakon nicanja kukuruza } \\
\text { Pore coefficient, e - after the germination of corn }\end{array}$ & $0,85^{\mathrm{ab}}$ & $0,81^{\mathrm{ab}}$ & $0,87^{\mathrm{a}}$ & $0,77^{\mathrm{b}}$ & $\mathbf{0 , 7 9}^{\mathrm{a}}$ \\
\hline $\begin{array}{l}\text { Koeficijent pora, e - nakon berbe kukuruza } \\
\text { Pore coefficient, e - after the harvest of corn }\end{array}$ & $0,79^{\mathrm{a}}$ & $0,79^{\mathrm{a}}$ & $0,79^{\mathrm{a}}$ & $\mathbf{0 , 7 6}^{\mathrm{a}}$ & $\mathbf{0 , 7 6}^{\mathrm{a}}$ \\
\hline $\begin{array}{l}\text { Koeficijent pora, e - nakon nicanja soje } \\
\text { Pore coefficient, e - after the germination of } \\
\text { soybean }\end{array}$ & $0,76^{\mathrm{a}}$ & $0,80^{\mathrm{a}}$ & $0,78^{\mathrm{a}}$ & $0,79^{\mathrm{a}}$ & $\mathbf{0 , 7 2}^{\mathrm{a}}$ \\
\hline $\begin{array}{l}\text { Koeficijent pora, e - nakon žetve soje } \\
\text { Pore coefficient, e - after the harvest of soybean }\end{array}$ & $0,70^{\mathrm{ab}}$ & $0,72^{\mathrm{ab}}$ & $\mathbf{0 , 6 9}$ & $0,76^{\mathrm{a}}$ & $0,72^{\mathrm{a}}$ \\
\hline
\end{tabular}


Između istraživanih načina obrade tla u stadiju nicanja pri uzgoju kukuruza utvrđene su opravdano manje vrijednosti koeficijenta pora (e) kod varijante D u odnosu na varijante $\mathrm{C}$ i E. Nakon berbe kukuruza nisu utvrđene statistički opravdane razlike. Iza žetve soje ustanovljene su opravdano manje vrijednosti parametra (e) kod varijante $\mathrm{C} u$ odnosu na varijante $\mathrm{D}$ i E, a opravdanih razlika u odnosu na varijante A i B nije bilo. U stadiju nicanja nisu utvrđene opravdane razlike između istraživanih načina obrade tla. Ipak se nakon nicanja soje varijanta E pokazala nepovoljnijom glede ovog parametra, a u žetvi najnepovoljnije stanje zabilježeno je kod varijante $\mathrm{C} \mathrm{s}$ osnovnom obradom provedenom u jesen, a dopunskom u proljeće. Iz izloženoga proizlazi, kako je kod varijante A (osnovna obrada u proljeće i priprema za sjetvu sjetvospremačem) utvrđeno najpovoljnije stanje parametra $\mathrm{R}$ i najmanja opasnost od stvaranja pokorice, iako i kod drugih primijenjenih načina obrade tla nije utvrđeno izrazito nepovoljno stanje s vrijednostima manjim od 5. Koeficijent pora (e) većinom je u obrnuto proporcionalnom odnosu s vrijednostima gustoće pakiranja čestica (Gp) i također ukazuje na uglavnom najnepovoljnije stanje zbijenosti tla pri uzgoju soje kod varijante E s najvećim brojem zahvata obrade, dok je u berbi kukuruza najnepovoljnije stanje zabilježeno kod varijanata D i E.

Većinom su najpovoljniji rezultati dobiveni kod varijante A, gdje je osnovna obrada tla obavljena u proljeće neposredno prije sjetve, a dopunska jednim prohodom sjetvo-spremača. Temeljem navedenoga, sa stanovišta održivog gospodarenja tlom, na pseudogleju pjeskovito ilovaste teksture može se preporučiti osnovna obrada tla u proljeće i njegova priprema sjetvospremačem. Špoljar i sur. (2011.) pri uzgoju kultura u plodoredu utvrđuju najpovoljnije stanje Boekelovih parametara koji ukazuju na opasnost od stvaranja pokorice i zbijanja tla zbog obrade nakon uzgoja lupine. Sa stanovišta održivog gospodarenja tlom i ublažavanja ovih nepoželjnih posljedica autori preporučaju uzgoj kultura u plodoredu te primjenu kombinirane organske $\mathrm{i}$ mineralne gnojidbe s primjenom kalcifikacije. Almajmamie i sur. (2017.) također navode da se opasnost od stvaranja pokorice može smanjiti unošenjem materijala za kalcifikaciju i organske tvari. Hamza i Anderson (2005.) također s ciljem ublažavanja nepoželjnih posljedica povećane zbijenosti tla preporučaju smanjenje osovinskog opterećenja, povećanje kontaktne površine kotača s tlom, smanjenje broja prohoda, povećanje sadržaja organske tvari te uvođenje onih kultura u plodored koje dobro rahle tlo. Zhang i sur. (2003.) također ističu, kako se degradacija strukture tla, njegovo prekomjerno zbijanje i površinska erozija mogu ublažiti povećanjem sadržaja organske tvari u tlu, a utvrđen je i pozitivan 
A. Špoljar i sur.: Parametri antropogenog zbijanja, kvarenja strukture i stvaranja pokorice kod različitih načina obrade tla

utjecaj na konzervaciju vlage tijekom sušnih mjeseci. Pri konvencionalnoj i reduciranoj obradi tla Gicheru i sur. (2004) utvrđuju značajno manju debljinu i čvrstoću pokorice na obje istraživane varijante kod primjene organske gnojidbe. Whalen i sur. (2003) također dobivaju pozitivan utjecaj sadržaja organske tvari na stabilnost strukturnih agregata kod konvencionalne i izostavljene obrade tla.

Temeljem izloženoga, s ciljem ublažavanja nepoželjnih posljedica povećane zbijenosti tla može se preporučiti smanjenje osovinskog opterećenja, povećanje kontaktne površine kotača s tlom, smanjenje broja prohoda, povećanje sadržaja organske tvari te uvođenje onih kultura u plodored koje dobro rahle tlo. Degradacija strukture i stvaranje pokorice može se učinkovito ublažiti povećanjem sadržaja organske tvari u tlu.

\section{ZAKLJUČAK}

Najpovoljnije stanje stabilnosti strukture (St), utvrđeno je kod varijante A kod koje su osnovna obrada i dopunska obrada sjetvo-spremačem provedene u proljeće, dok je najnepovoljnije stanje utvrđeno kod varijante E $\mathrm{s}$ najvećim brojem zahvata obrade. Najveća vrijednost ovog parametra i najmanja opasnost od zbijanja tla i erozije zabilježena je nakon uzgoja soje. Najveće vrijednosti gustoće pakiranja čestica tla $(\mathrm{Gp})$ bile su nakon berbe kukuruza kod varijanata D i E kod kojih je osnovna obrada tla provedena u jesen. $U$ isto vrijeme nakon berbe kukuruza utvrđene su i najniže vrijednosti koeficijenta pora (e), koji također ukazuje na nepovoljnije stanje zbijenosti tla. Pri uzgoju soje po varijantama obrade nisu utvrđene statistički opravdane razlike gustoće pakiranja čestica $(\mathrm{Gp})$, pa se može pretpostaviti da tu do izražaja dolazi i utjecaj uzgajanog usjeva. U obje godine istraživanja utvrđen je najmanji rizik od stvaranja pokorice (R) kod varijante A, a najveća vrijednost ovog parametra zabilježena je nakon uzgoja soje. S ciljem ublažavanja nepoželjnih posljedica povećane zbijenosti tla može se preporučiti smanjenje osovinskog opterećenja, povećanje kontaktne površine kotača $\mathrm{s}$ tlom, smanjenje broja prohoda, povećanje sadržaja organske tvari te uvođenje onih kultura u plodored koje dobro rahle tlo. Degradacija strukture i stvaranje pokorice mogu se učinkovito ublažiti povećanjem sadržaja organske tvari u tlu. Temeljem navedenoga, sa stanovišta održivog gospodarenja tlom, na pseudogleju pjeskovito ilovaste teksture može se preporučiti osnovna obrada tla u proljeće i njegova priprema sjetvo-spremačem. 
A. Špoljar i sur.: Parametri antropogenog zbijanja, kvarenja strukture i stvaranja pokorice kod različitih načina obrade tla

\section{LITERATURA}

1. Almajmamie, A., Hardie, M., Acuna, T., Birch, C. (2017.): Can soil crusting be reduced through application of gypsum, organic waste, and phosphoric acid? Journal of soil and water conservation. 72/6: 597-606.

2. Bogunović, I., Kisić, I., Jurišić, A. (2014.): Soil Compaction under Different Tillage System on Stagnic Luvisols. Agriculturae Conspectus Scientificus . 79(1): 57-63.

3. Batey (2009.): Soil compaction and soil management - a review. Soil Use and Land Management, 25 (4): 335-345.

4. Dorner, J., Dec, D., Zuniga, F., Sandoval, P., Horn, R. (2011.): Effect of land use change on Andosol's pore functions and their functional resilience after mechanical and hydraulic stress. Soil Tillage Research, 115-116. 71-79.

5. Frey, B., Kremer, J., Rudt, A., Sciacca, S., Mathies, D., Luscher, P. (2009.): Compaction of forest soils with heavy logging machinery affects soil bacterial community structure. European Journal of Soil Biology, 45 (4): 312-320.

6. Gabriels, D., Verdoodt, A. (2012.): Soil Degradation. Universitet Gent, Faculty of Bioscience Engineering, 244 p.

7. Gicheru, P., Gachene, C., Mbuvi, J., Mare, E. (2004.): Effects of soil management practices and tillage systems on surface soil water conservation and crust formation on a sandy loam in semi-arid Kenya. Soil \& Tillage Research 75: 173-184.

8. Guan, D., Zhang, Y., Al-Kaisi, M.M., Wang, O., Zhang, M., Li, Z. (2015.): Tillage practices effect on root distribution and water use efficiency of winter wheat under rain-fed condition in the North China Plain. Soil \&Tillage Research. 196: 285-296.

9. Hamza, M.A., Anderson, W.K. (2005.): Soil compaction in cropping systes: A review of nature, causes and possible solutions. Soil and Tillage Research, 82 (2): 121-145.

10. Krebstein, K., Von Janovsky, K., Reintam, E., Horn, R., Leeduks, J., Kuht, J. (2013.): Soil compaction in a Cambisol under grassland in Estonia. Zemdirbyste-Agriculture, 100 (1): 33-38.

11. Kozlowski, T.T. (2008.): Soil compaction and growth of woody plants. Scandinavian Journal of Forest Research, 14(6): 596-619.

12. Kvaternjak, I., Kisić, I., Birkas, M., Špoljar, A., Marenčić, D. (2015.): Yields and components of maize (Zea mays L.) and soybean (Glycine max. L.) as affected by different tillage methods. Ekologia (Bratislava), 34 (4): 371-379. 
A. Špoljar i sur.: Parametri antropogenog zbijanja, kvarenja strukture i stvaranja pokorice kod različitih načina obrade tla

13. Martinez, L.J., Zinck, J.A. (2014.): Temporal variation of soil compaction and degradation of soil quality in pasture areas of Colombian Amazonia. Soil and Tillage Research, 75: 3-17.

14. Oduma, O., Nnadi, D.C., Agu, S. Igwe, J.E. (2017.): Determination of the Effect of Tillage on Soil Resistance to Penetration. A Study of South-East Agricultural Soils. American Journal of Engineering Research.6 (7):1-5.

15. Pagliai, M., Vignozzi, N., Pellegrini, S. (2004.): Soil structure and the effect of management practices. Soil \&Tillge Research. 79:131-143.

16. Racz, Z. (1981.): Meliorativna pedologija. II dio, Sveučilište u Zagrebu, Zagreb.

17. Shah, A.N., Tanveer, M., Shahzad, B., Yang, G., Fahad, S., Ali, S., Bukhari, M.A., Tung, S.A., Hafeez, A., Souliyanonh, B. (2017.): Soil compaction effects on soil health and crop productivity: An overview. Environment Science Pollution Research. 24/1056-1057. Springer-Verlag Berlin Heidelberg.

18. Soane, B.D., Van Ouwerkerk, C. (1995.): Implications in crop production for quality of the environment. Soil and Tillage Research, 35 (1-2): 5-22.

19. SSEW (1976.): Soil Survey Field and Handbook. Tech., Monograph No 5., Edited by J.M.Hodgson, Harpenden.

20. Špoljar, A., Kisić, I., Birkas, M., Gunjača, J., Kvaternjak, I. (2011.): Influence of crop rotation, liming and green manuring on soil properties yield. Journal of Environmental Protection and Ecology, 12 (1):54-69.

21. Špoljar, A., Kvaternjak, I., Slunjski, D. (2014.): Mehanički otpor tla u vinogradima različite starosti. Agronomski glasnik, 6: 267-276.

22. Tracy, S.R., Black, C.R., Roberts, J.A., Mooney, S.J. (2011.). Soil compaction: a review and present techniques for investigation effects on root growth. Science of Food and Agriculture, 91 (9): 1528-1537.

23. Whallen, J.K., Quancai, H., Liu, A. (2003.): Compost Applications Increase Water-Stable Aggregates in Conventional and No-Tillage Systems. Soil Sci. Soc. Am. J., 67:1842-1847.

24. Zhang, B., Horn, R., Hallett, D. (2003.): Mechanical Resilience of Degraded Soil Amended with Organic Matter. Soil and Water Management and Conservation, 69 (3): 864-871.

25. https://www.polj.savetodavstvo.gov.vojvodina.rs (23. rujna 2017).

26. Statistica 12.1. (StafSoft, Inc. 2012.) 
A. Špoljar i sur.: Parametri antropogenog zbijanja, kvarenja strukture i stvaranja pokorice kod različitih načina obrade tla

Adresa autora - Author's address:

Dr. sc. Andrija Špoljar, prof. v. š.,

e-mail: aspoljar@vguk.hr

25.05.2018.

Dr. sc. Ivka Kvaternjak, prof. v. š.

Visoko gospodarsko učilište u Križevcima,

M. Demerca 1, 48 210, Križevci, Hrvatska

Prof.dr. sc. Ivica Kisić, e-mail: ikisic@agr.hr

Agronomski fakultet Sveučilišta u Zagrebu,

Svetošimunska cesta 25, Zagreb, Hrvatska 